\title{
A new species of Spirophilometra (Nematoda: Philometridae) from the yellowfin snook Centropomus robalito (Osteichthyes) in southern Mexico
}

\author{
František Moravec $^{1}$, Ana María Santana-Piñeros ${ }^{2}$, David González-Solís ${ }^{3}$ and Ana María Torres-Huerta ${ }^{2}$ \\ ${ }^{1}$ Institute of Parasitology, Biology Centre, Academy of Sciences of the Czech Republic, Branišovská 31, 37005 České \\ Budějovice, Czech Republic; \\ ${ }^{2}$ Instituto de Recursos, Universidad del Mar, Campus Puerto Ángel, Ciudad Universitaria, C.P. 70902, Puerto Ángel, Oaxaca, \\ Mexico; \\ ${ }^{3}$ Laboratorio de Necton, El Colegio de la Frontera Sur (ECOSUR), Unidad Chetumal, Av. Centenario Km. 5.5, C.P. 77900, \\ A.P. 424, Chetumal, Quintana Roo, Mexico;
}

Key words: parasitic nematode, Spirophilometra, marine fish, Centropomus, Mexico

\begin{abstract}
A new nematode species, Spirophilometra pacifica sp. n. (Philometridae), is described from gravid female specimens collected from the mouth cavity (the upper palate) of the fish (yellow snook) Centropomus robalito (Centropomidae, Perciformes) from the Chantuto-Panzacola system, Chiapas, in the Pacific coast of Mexico. Its morphology is very similar to that of the species originally described as Philometra centropomi Caballero, 1974, but the gravid females of S. pacifica are about three times longer (body length 11.63-18.17 mm); host species and the geographical distribution of both these forms also differ. Scanning electron microscope (SEM) examination of S. pacifica, used for the first time for a Spirophilometra species, confirmed the presence of numerous minute cuticular spines on the body surface, 14 cephalic papillae arranged in two circlets, and two small lateral papilla-like caudal projections. It is evident that some features of $P$. centropomi were incorrectly described (its types are not available) and this species is now transferred to Spirophilometra as S. centropomi (Caballero, 1974) comb. n.
\end{abstract}

The nematode family Philometridae Baylis et Daubney, 1926 contains a large number of species parasitic in the abdominal cavity and various body tissues of freshwater, brackish-water and marine fishes; most of them are known only by their large-sized females (Moravec 2004, 2006). At present, the family includes 11 valid genera (Moravec 2006). In Mexico, five species of philometrids belonging to two genera were reported: Neophilometroides caudatus (Moravec, Scholz et Vivas-Rodríguez, 1995) from the swimbladder of the freshwater catfish Rhamdia guatemalensis (Günther), Philometra ophisterni Moravec, Salgado-Maldonado et Aguilar-Aguilar, 2002 from the mesentery of the freshwater swamp-eel Ophisternon aenigmaticum Rosen et Greenwood, Philometra centropomi Caballero, 1974 from the nasal mucosa of the marine fish Centropomus undecimalis (Bloch), and Philometra margolisi Moravec, Vidal-Martínez et Aguirre-Macedo, 1995 and Philometra salgadoi Vidal-Martínez, Aguirre-Macedo et Moravec, 1995 from the gonads and ocular cavities, respectively, of the marine fish (red grouper) Epinephelus morio (Valenciennes) (Caballero 1974, Moravec et al. 1995a,b, 2001, 2002a,b, Vidal-Martínez et al. 1995). Five additional representatives of the philometrid genera Philometra Costa, 1845 and Philometroides Yamaguti, 1935 were reported from marine and brackish-water fishes from southern Mexico in an unpublished $\mathrm{PhD}$ thesis by González-Solís (2001).
During recent studies on the parasites of some marine fishes in the Chantuto-Panzacola system, carried out by researchers from the Universidad del Mar, a few gravid females of philometrid nematodes were collected from the yellow snook Centropomus robalito Jordan et Gilbert (Centropomidae, Perciformes), which proved to represent a previously undescribed species of Spirophilometra Parukhin, 1971. The species is described herein. The yellow snook is a pelagic marine and brackish-water fish up to $35 \mathrm{~cm}$ long, distributed in the Eastern Pacific from the Gulf of California to northern Colombia; it is important as a commercial fish and a gamefish (Froese and Pauly 2007).

\section{MATERIALS AND METHODS}

The fish were obtained from the traditional fishery in the Chantuto-Panzacola system. The nematodes recovered were washed in physiological saline and then fixed in $4 \%$ hot formaline. For light microscopical examination, the nematodes were cleared with glycerine. Drawings were made with the aid of a Zeiss drawing attachment. Specimens used for scanning electron microscopy (SEM) were postfixed in $1 \%$ osmium tetroxide, dehydrated through a graded ethanol series, critical point dried and sputter-coated with gold; they were examined using a JEOL JSM-6300 scanning electron microscope at an accelerating voltage of $15 \mathrm{kV}$. All measurements are in micrometres unless otherwise stated. The names of fishes follow Froese and Pauly (2007). 


\section{DESCRIPTION}

Spirophilometra pacifica sp. n.

Figs. 1, 2

Gravid female (4 larvigerous specimens; measurements of holotype in parentheses): Body of fixed specimens brownish, cylindrical, markedly tapering at both ends, 11.63-18.17 (16.55) mm long, maximum width 490-585 (585). Maximum width/length ratio of body 1:2.9-4.2 (1:3.5). Cuticle of entire body densely transversely striated and covered with minute spines up to 3 (3) high, mostly arranged in transverse rows; many spines reduced to tiny sclerotized papilla-like formations (Fig. 2F). Cephalic papillae fairly large, distinct when viewed laterally. Oral aperture large, oval, surrounded by four pairs of submedian cephalic papillae of external circle and six ( 2 lateral and 4 submedian) single papillae of internal circle; each external pair formed by one smaller, almost rounded papilla and one larger elongate papilla (Figs. 1C, 2A). Two small lateral amphids present. Deirids absent. Bottom of mouth formed by flat surfaces of three oesophageal sectors. Anterior end of oesophagus swollen to form well-developed bulb 33-42 (42) long and 51-57 (57) wide. Long posterior portion of oesophagus provided with well-developed, broad oesophageal gland extending anteriorly to about mid-length of distance between nerve ring and anterior extremity; oesophageal gland contains large cell nucleus located somewhat posterior to its middle, at $680-857$ (not observed) from anterior extremity. Overall length of oesophagus including anterior bulb 1.01-1.28 (1.13) mm, representing 7-9 (7) \% of body length; maximum width of its posterior part including oesophageal gland 95-163 (95). Small ventriculus, 15-30 (30) long and 21-42 (42) wide, opening into intestine through valve. Nerve ring 136-163 (150) from anterior end of body. Intestine light-brown, narrow, its posterior end atrophied, forming short ligament 33-120 (33) long attached subventrally to body wall near posterior extremity. Posterior end of body narrowed, 81-95 (81) wide, rounded, bearing two distinct lateral papilla-like projections (Figs. 1F, I, 2E). Ovaries relatively short, narrow, reflected. Uterus occupying major part of body, extending anteriorly to some distance posterior to nerve ring. Uterus filled with numerous larvae 345-390 (351-363) long and 12-15 (12-15) in maximum width $(\mathrm{n}=8)$, with slender, sharply pointed tail.

Male: Unknown.

T y p e h o s t: Yellow snook, Centropomus robalito Jordan et Gilbert (Centropomidae, Perciformes).

Site of infection: Mouth cavity.

$\mathrm{T}$ y p e 1 o c a 1 i t y : Chantuto-Panzacola system, Mexico $\left(14^{\circ} 43^{\prime}-15^{\circ} 40^{\prime} \mathrm{N}, 92^{\circ} 26^{\prime}-93^{\circ} 20^{\prime} \mathrm{W}\right)$ (August 2006).

Prevalence and intensity : Prevalence $8.7 \%(2$ fish infected / 23 fish examined); intensity 1 and 4 nematodes.

De pos ition of types: Holotype in the Helminthological Collection of the Instituto de Biología, UNAM,
Mexico City (CNHE 5839); 1 paratype in the Helminthological Collection of the Institute of Parasitology, Biology Centre of the ASCR, České Budějovice (N-873), and 1 paratype in the Universidad del Mar, Oaxaca.

\section{DISCUSSION}

The general morphology of nematodes of the present material somewhat resembles that of Philometra centropomi Caballero, 1974, particularly in relatively small body measurements of gravid females, presence of minute spines on their cuticle, comparatively large cephalic papillae, and a well-developed anterior bulbous inflation on the oesophagus. Philometra centropomi was described by Caballero (1974) from four available females collected from the nasal mucosa of the common snook Centropomus undecimalis (Bloch) of the Lagoon of Chairel (Laguna de Chairel), Tamaulipas, eastern Mexico and it has not been recorded since. Although Caballero (1974) mentioned that the holotype of P. centropomi was in the Helminthological Collection of the Instituto de Biología, UNAM under the Coll. No. 162-1, Lamothe-Argumedo et al. (1997) reported P. centropomi under the catalogue number 2610 (F), remarking, however, that the material of this species was not deposited in this collection; according to information by $\mathrm{R}$. Lamothe-Argumedo (pers. comm.), the type specimens of $P$. centropomi remained in the personal collection of G. Caballero-Rodríguez. Recent attempts of the senior author (F.M.) to contact Dr. Caballero-Rodríguez were unsuccessful.

In his recent monograph treating dracunculoids, Moravec (2006) considered some features reported for $P$. centropomi (e.g., presence of a vulva, deirids and cuticular spines, structure of the oesophagus) to be unreliable and, therefore, he retained it in Philometra for the time being; he suggested, however, that it probably does not belong to this genus. The types of $P$. centropomi are not available for a re-examination and a new study of this species will depend on the collection of topotypical materials. However, it can be deduced from the morphology of specimens of the present material collected from a congeneric host, which undoubtedly represent a closely related species, that the minute cuticular spines were described correctly in $P$. centropomi, whereas the alleged presence of the vulva and deirids or the described structure of the oesophagus were evidently based on erroneous observations.

Principally by having the cuticle of the entire body of gravid females densely covered with transverse rows of minute spines, both philometrid forms from Centropomus spp. can be assigned to the monotypic genus Spirophilometra Parukhin, 1971. The only species of this genus, S. eichleri Parukhin, 1971, was described from gravid females collected from the spleen and males from the gonads of the marine fish (spangled emperor) Lethrinus nebulosus (Forsskål) (Lethrinidae, Perciformes) from the Gulf of Saukara, Indian Ocean 

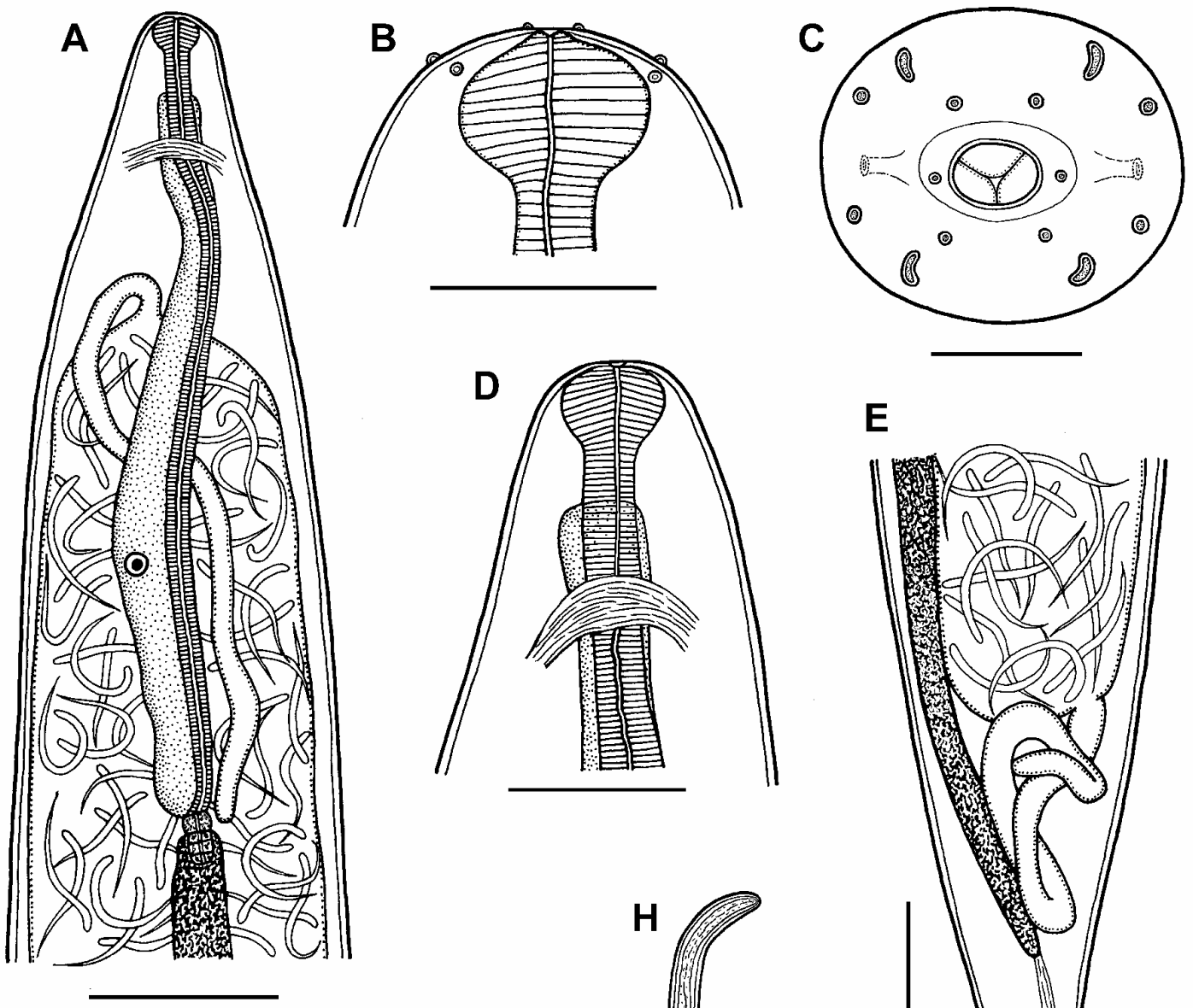

\section{$\mathbf{E}$}
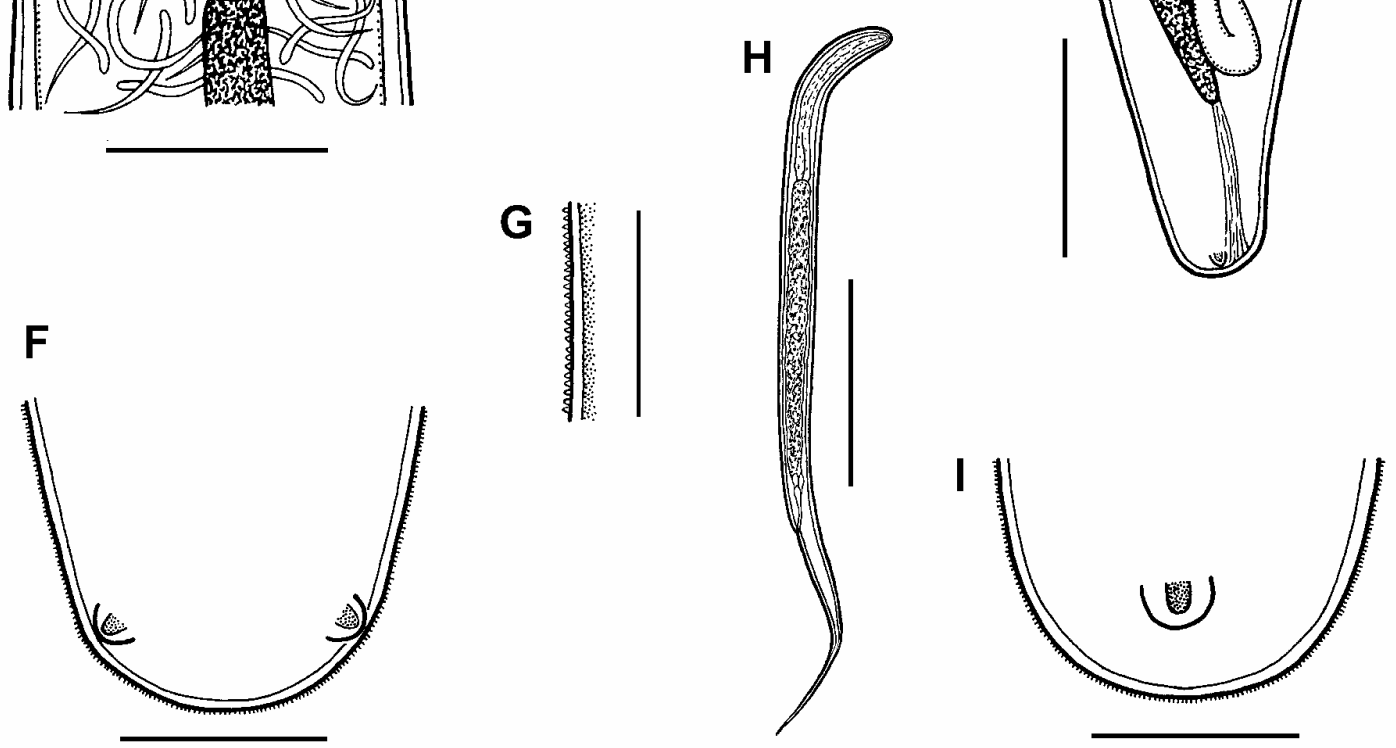

Fig. 1. Spirophilometra pacifica sp. n., gravid female. A - anterior end of body; B, C - cephalic end, lateral and apical views; $\mathbf{D}$ - anterior end, lateral view; $\mathbf{E}$ - posterior end of body, lateral view; $\mathbf{F}$ - caudal end, dorsoventral view; $\mathbf{G}$ - spines on cuticle, lateral view; H - larva from uterus; I - caudal end, lateral view. Scale bars: A, E $=200 \mu \mathrm{m} ; \mathrm{B}, \mathrm{F}, \mathrm{I}=50 \mu \mathrm{m} ; \mathrm{C}=20 \mu \mathrm{m} ; \mathrm{D}, \mathrm{H}=$ $100 \mu \mathrm{m} ; \mathrm{G}=30 \mu \mathrm{m}$.

(Parukhin 1971, 1973). Except for the presence of a bulbous oesophageal inflation, which is allegedly absent in S. eichleri, both $P$. centropomi and the newly collected specimens from Centropomus robalito agree well with the diagnosis of Spirophilometra. Therefore, both of them are considered to belong to this genus, where the former is transferred as Spirophilometra centropomi (Caballero, 1974) comb. n.

It has been mentioned above that the morphology of the present nematodes from Centropomus robalito seems to be very similar to or even identical with that of S. centropomi, because some reported distinguishing 

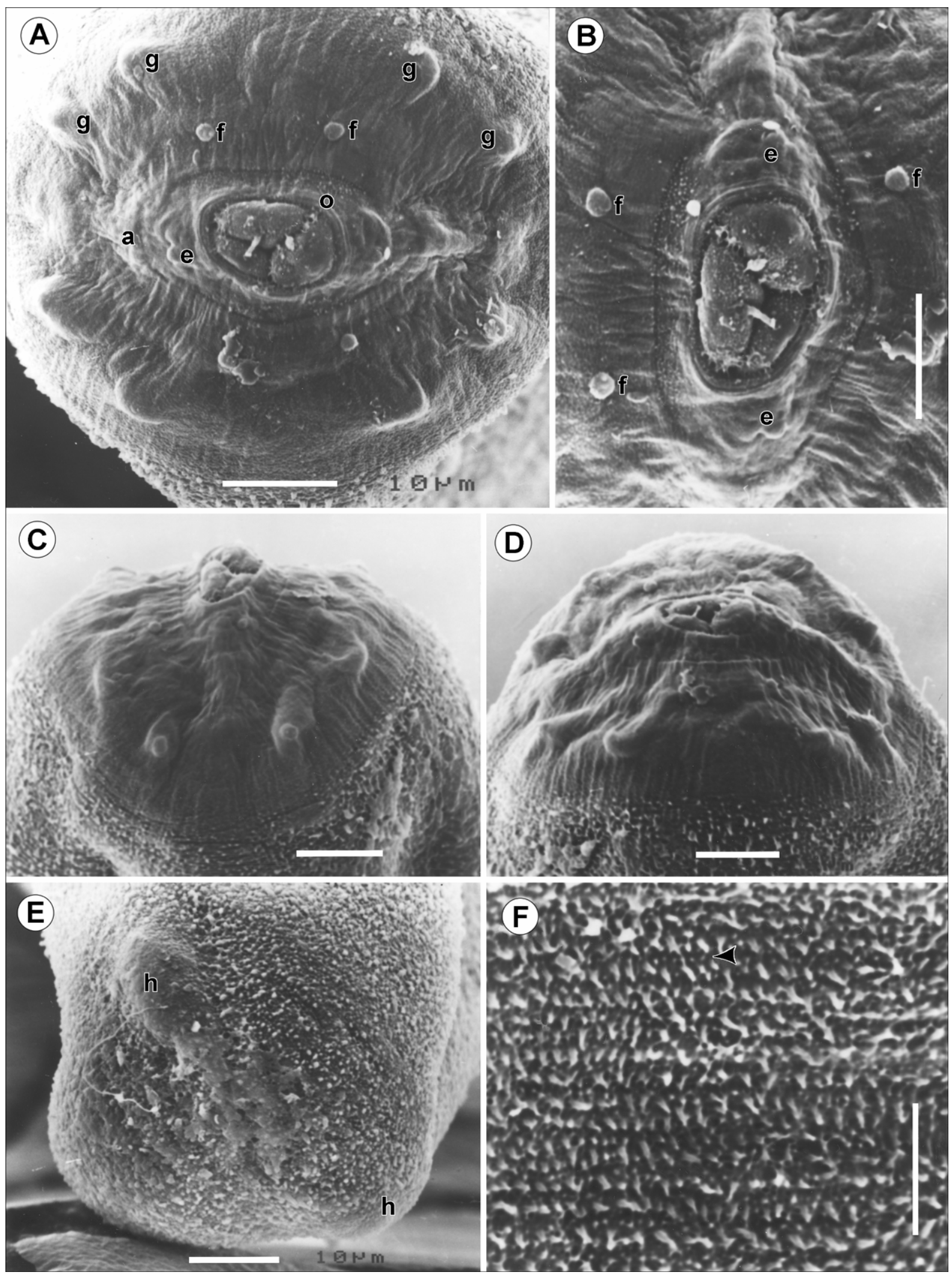

Fig. 2. Spirophilometra pacifica sp. n., scanning electron micrographs of gravid female. A - cephalic end, apical view; $\mathbf{B}-\mathrm{re-}$ gion of mouth, apical view; C, D - cephalic end, lateral and subventral views; $\mathbf{E}$ - caudal end, sublateral view; $\mathbf{F}$ - cuticular spines on middle part of body (arrow indicates row of reduced spines). a - amphid; e - lateral cephalic papilla of internal circle; $\mathrm{f}$ - submedian cephalic papilla of internal circle; $\mathrm{g}$ - submedian cephalic papilla of external circle; $\mathrm{h}$ - caudal projection; $\mathrm{o}$ - margin of oral aperture. All scale bars $=10 \mu \mathrm{m}$. 
characters (presence of a vulva, deirids and a markedly short oesophagus) of the latter were apparent mistakes; probably only the anterior part of the oesophagus was taken for a complete oesophagus of $S$. centropomi by Caballero (1974), whereas its longer posterior part provided with a large oesophageal gland, usually overlapped by the uterus with larvae, was overlooked. However, in the situation when the types of $S$. centropomi cannot be re-examined and there are conspicuous differences in the body size of gravid females between $S$. centropomi and the nematodes of the present material (body length $3.3-6.2 \mathrm{~mm}$ vs. $11.6-18.2 \mathrm{~mm}$ ), it is reasonable to consider the latter to represent an independent new species, Spirophilometra pacifica. This is supported by the fact that they also differ in their geographical distribution (southern Gulf of Mexico vs. Pacific coast of Mexico) and the distribution areas of their host species are found in different oceans (C. undecimalis in Western Atlantic vs. C. robalito in Eastern Pacific) (Froese and Pauly 2007).

Spirophilometra pacifica differs from $S$. eichleri, the type species of the genus, in the presence of an anterior bulbous inflation of the oesophagus in gravid females, in a much longer oesophagus (1.01-1.28 mm vs. 0.46 $\mathrm{mm}$ ) and much longer larvae from the uterus (345-390 $\mu \mathrm{m}$ vs. $140-160 \mu \mathrm{m})$; in contrast to $S$. pacifica, neither cephalic papillae nor caudal protrusions were observed in S. eichleri; their hosts belong to different fish families (Centropomidae vs. Lethrinidae) and occur in different
(Pacific vs. Indian) oceans. The males of S. pacifica (as well as those of $S$. centropomi) remain unknown. Parukhin (1971) described philometrid males from the gonads of Lethrinus nebulosus and considered them to belong to $S$. eichleri; however, considering their site of infection, it may well be that, in fact, they belonged to another philometrid, a species of Philometra Costa, 1845 parasitizing gonads of marine fishes; both males and females of a Philometra sp. were recently found in the gonads of L. nebulosus off New Caledonia (Moravec and Justine, unpubl.).

Spirophilometra pacifica is the first species of this genus examined by SEM. This study confirmed the presence of a unique feature among philometrids, the presence of minute cuticular spines in gravid females, and showed that the number and distribution of cephalic papillae in Spirophilometra are typical of many representatives of other philometrid genera (Moravec 2004, 2006). Spirophilometra pacifica is the sixth species of the Philometridae reported from Mexican waters.

Acknowledgements. This study was supported by the Comisión Nacional de Ciencia y Tecnología, Gobierno de Chiapas (CHIS-2005-C03-106), the grant 524/06/0170 from the Grant Agency of the Czech Republic and by the research projects of the Institute of Parasitology, ASCR (Z60220518 and LC522). Thanks are due to the staff of the Laboratory of Electron Microscopy, Institute of Parasitology, Biology Centre of the ASCR, in Ceské Budějovice for technical assistance, and Irena Husáková, Department of Helminthology at the same Institute, for help with illustrations.

\section{REFERENCES}

CABAllero R.G. 1974: Contribución al conocimiento de los nemátodos de peces de los litorales de México. III. Dos nuevas formas. Publicaciones Biológicas del Instituto de Investigaciones Científicas de la Universidad Autónoma de Nuevo León, Monterrey, 1: 33-40.

Froese R., Pauly D. (Eds.) 2007: FishBase. World Wide Web electronic publication, www.fishbase.org, version 05/2007.

GONZÁLEZ-SOLÍS D. 2001: Nematodes (Nematoda) as the parasites of fishes in the conditions of southern Mexico. PhD thesis, Institute of Parasitology, Academy of Sciences of the Czech Republic, České Budějovice, 152 pp.

LAMOTHE-ARGUMEDO R., GARCIA-PRIETO L., OSORIO-SARABIA D., PEREZ-Ponce DE LEON G. 1997: Catálogo de la Colección Nacional de Helmintos. Instituto de Biología, Universidad Nacional Autónoma de México, México, 211 pp.

MORAVEC F. 2004: Some aspects of the taxonomy and biology of dracunculoid nematodes parasitic in fishes: a review. Folia Parasitol. 51: 1-13.

MORAVEC F. 2006: Dracunculoid and Anguillicoloid Nematodes Parasitic in Vertebrates. Academia, Prague, 634 pp.

Moravec F., SAlgado-Maldonado G., Aguilar-Aguilar R. 2002a: Neophilometroides n. gen. (Nematoda: Philometridae) for Philometroides caudatus Moravec, Scholz and VivasRodríguez, 1995, with erection of Neophilometroidinae n. subfam. J. Parasitol. 88: 774-777.

Moravec F., SAlgado-Maldonado G., Aguilar-Aguilar R. 2002b: Two new nematodes, Paraseuratoides ophisterni gen. et sp. n. (Quimperiidae) and Philometra ophisterni sp. n.
(Philometridae), from the swamp-eel Ophisternon aenigmaticum in Mexico. Folia Parasitol. 49: 109-117.

Moravec F., Scholz T., Vivas-Rodríguez C. 1995a: Philometroides caudata sp. n. (Nematoda: Philometridae) from Rhamdia guatemalensis (Pisces) in Yucatan, Mexico. Folia Parasitol. 42: 293-298.

Moravec F., VidAl-Martínez V.M., AguirRe-Macedo M.L. 1995b: Philometra margolisi n. sp. (Nematoda: Philometridae) from the gonads of the red grouper, Epinephelus morio (Pisces: Serranidae), in Mexico. Can. J. Fish. Aquat. Sci. (Suppl. 1) 52: 161-165.

MoraveC F., VidAl-MartíneZ V.M., AGUIRRE-MACEdo M.L., GONZÁLEZ-SOLÍS D. 2001: First description of the male and redescription of the female of Philometra salgadoi VidalMartínez et al., 1995 (Nematoda: Philometridae) from the ocular cavity of the marine fish Epinephelus morio in Mexico. Parasitol. Res. 87: 526-529.

PARUKHIN A.M. 1971: Spirophilometra eichleri n. g. n. sp., ein neuer Fisch-Nematode aus dem Indik. Angew. Parasitol. 12: 220-224.

PARUKHIN A.M. 1973: [Nematodes of fishes of the southern seas.] In: Biologiya Morya 31. Naukova Dumka, Kiev, pp. 162-177. (In Russian.)

Vidal-Martínez V.M., Aguirre-Macedo M.L., Moravec F. 1995: Philometra (Ranjhinema) salgadoi n. sp. (Nematoda: Philometridae) from the ocular cavity of the red grouper Epinephelus morio (Pisces: Serranidae) from the Yucatan Peninsula, Mexico. J. Parasitol. 81: 763-766. 